\title{
How Knowledge Management Implementation Affects The Performance Of Egyptian Construction Companies
}

\author{
Ahmed ElFar, Pioneers Holding Co., Egypt \\ Abdel Moneim Elsaid, Ain Shams University, Egypt \\ Eahab Elsaid, University of Windsor, Canada
}

\begin{abstract}
This study examines the effectiveness of knowledge management systems within the construction industry in Egypt from the perspective of knowledge infrastructure capability (KIC), knowledge process capability (KPC) and their impact on business performance (BP) from the financial, consumer, learning and growth, supplier and internal perspectives. The sample consists of 75 first class Egyptian construction companies. The authors used a questionnaire that was modified from the questionnaire previously used by Gold, Malhotra and Segars (2001) and Smith (2006). The authors used one-way ANOVA, t-tests and OLS regressions. The results indicated that both knowledge infrastructure capability (KIC) and knowledge process capability (KPC) have a positive effect on business performance (BP). The results also indicate that organizations with well-developed training and development plans have significantly higher KIC and KPC scores compared to those that do not have such plans.
\end{abstract}

Keywords: Egypt; Knowledge Management; Construction Industry; Business Performance; Knowledge Infrastructure Capability; Knowledge Process Capability

\section{INTRODUCTION}

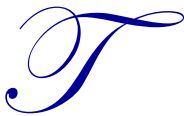

wo of main characteristics of today's business environment are complexity and uncertainty. Most organizations, including construction companies, have a competitive advantage depending on the knowledge available to them. To maintain this competitive advantage in a dynamic environment, companies must keep developing their knowledge management strengths in order to build and improve their knowledge resources over time. Although the term knowledge management is relatively new, the application of knowledge management is not new (Robinson, Carrillo, Anumba \& Al-Ghassani, 2004). The main challenge in a knowledge-based economy is to be innovative and to continuously improve products, services and processes (Robinson et al., 2004). Knowledge management is defined as any process of creating, acquiring, capturing, sharing and using knowledge in order to enhance learning and performance in organizations (Robinson et al., 2004; Scarborough, Swan \& Preston, 1999). The goal of the study is to examine the effectiveness of the knowledge management system within Egyptian construction companies from the perspective of Knowledge Infrastructure Capability (KIC) and Knowledge Process Capability (KPC) and its impact on business performance from financial, consumer, learning and growth, supplier and internal perspectives.

The construction industry is a knowledge-driven industry. The main challenge for any construction firm is time and cost of the project. Accordingly, knowledge management when implemented properly will provide employees with necessary knowledge in a fast and reliable method which will likely lead to better business performance when it comes to project cost and time. The construction companies' competitive advantage is directly linked to the effectiveness of their knowledge management system. An effective knowledge management system will encourage individuals within the same organization to create, share and protect knowledge. Mohamed and Anumba (2006) indicated that there is no accepted model when it comes to guiding construction companies in effectively implementing knowledge management. Chen and Mohamed (2005) stated that the number of empirical studies on knowledge management in construction companies worldwide is very limited (Serra, Ribeiro \& Grilo, 2012). 


\section{Categorizations of Knowledge Management}

In the knowledge management literature, the "knowledge" and "information" are two different concepts. AlHawamdeh (2002) argued that "information" must be transferred to "knowledge" in order to be shared and transferred. The proposed classification of knowledge management is similar to the classification proposed by Maier and Remus (2002). Knowledge management is classified into the following five categories:

1. Ontology of Knowledge and Knowledge Management

2. Knowledge Management Systems

3. Role of Information Technology

4. Managerial and Social Issues

5. Knowledge Measurement

Ontology of Knowledge and Knowledge Management

Moteleb and Woodman (2007) and Kidwell, Vander Linde and Johnson (2000) argued that knowledge begins with "data" which after being processed produces "information" which when mixed with practice becomes "knowledge" that is used in decision making. Nonaka and Takeuchi (1995) identified knowledge management as "the process of applying a systematic approach to the capture, structuring, management, and dissemination of knowledge throughout an organization to work faster, reuse best practice, and reduce costly rework from project to project." According to the above definition, the linkage between knowledge management and the organizational strategy must ensure that employees are familiar with the knowledge management objectives in order to improve corporate performance.

Polanyi (1967) identified two kinds of knowledge: explicit and tacit. Robinson et al., (2004) defines explicit knowledge as "codifiable knowledge inherent in the so-called non-human storehouses including organizational manuals on processes and procedures, databases, marketing channels and consumer relationship management systems. Explicit knowledge is, therefore, easily shared with other people or parts of an organization. Examples of explicit knowledge in construction are design codes of practice, manuals on construction standards and specifications." Grant (2007) defines tacit knowledge as "an individual's judgment and experiences and cannot be articulated or stored."

\section{Knowledge Management Systems}

Nidumolo, Subramani and Aldrich (2005) identified knowledge management systems as "focusing on grouping the explicit knowledge that exists in organizations, the know-how that can be easily documented and shared." Alavi and Leidner (2001) indicated that there are three procedures to design a successful knowledge management systems: codification, personalization, and people-finder.

i- The codification approach, also referred to as the "hard" approach, has as a starting point of bringing together knowledge, store it in powerful databases, using people to document strategy and prepare it to be retrieved by decision makers.

ii- The personalization approach, also referred to as the "soft" approach, tends to transfer knowledge by using face-to-face interactions. The IT role is limited to connecting people to facilitate tacit knowledge circulation. More investment is made in motivating people who are sharing their knowledge.

iii- The people-finder approach tends to locate the knowledge location within the organization and not the knowledge itself. Lloria (2008) argued that the people-finder approach facilitates the finding of people who have certain knowledge within the organization as well as to ensure their accessibility to be consulted or to share their knowledge.

Ragab and Aricha (2013) concluded that the knowledge management systems can be grouped into four core categories: "knowledge creation and acquisition, knowledge storage and retrieval, knowledge transfer and sharing, and knowledge application". 
Role of Information Technology

The role of Information Technology (IT) in knowledge management is thoroughly discussed in the knowledge management literature. Lindvall, Rus and Sinha (2003) indicated that there is no comprehensive software for the knowledge management systems. Any software may be used in knowledge acquisition, application and protection. Grace (2009) argued that the massive growth in the use of the internet will help in managing knowledge management within organizations.

Unfortunately, some organizations started to adopt a full IT-based system for knowledge management based on the unrealistic expectations that this will lead to successful knowledge management. These initiatives did not succeed as it neglected that knowledge management depends on processes accomplished by the human brain with integration of social, cultural and socio-cultural interconnectivity which is neglected by IT. IT-based systems have limited capabilities compared to human brains in knowledge management as they are only focused on explicit knowledge that can be codified and totally neglect the explicit knowledge sources. The second reason for failure of total IT-based systems in knowledge management was the wrong assumption that people, by default, tend to share their knowledge (Lindvall et al., 2003). Mohamed and Anumba (2006) concluded that "IT as a perfect solution will fail. Equally, the knowledge management initiative that undervalues IT will follow suit."

\section{Managerial and Social Issues}

Davenport and Prusak (2000) indicated that one of the recurring issues that affects the knowledge management implementation was the resistance of the employees to share knowledge with their counterparts for fear of potential job loss and reducing the probability of being promoted while increasing the probability of their counterparts with whom they share their knowledge being promoted. Unfortunately, in today's organizational systems, knowledge sharing is not rewarded and knowledge hiding is not prohibited. Davenport and Prusak (2000) also stated that "over and above, knowledge exchange may be negatively evaluated as time waste." To solve this conflict, Human Resource Management supports the knowledge management implementation by motivating employees who are sharing their knowledge and engaging them in knowledge management system creation.

Al-Adaileh and Al-Atawi (2011) have argued that organizational culture is essential for the success of knowledge management by supporting knowledge sharing. Kannabiran and Pandyan (2010) indicated that a knowledge management governance system can be formed within the organizational structure and can be led by the organization's Chief Knowledge Officer. Chen and Huang (2007) stated that knowledge sharing increases within decentralized, flat organizations with few hierarchal levels.

Shen and Liu (2003) and Cheng, Li and Love (2000) identified the key factors that lead to knowledge management success as follows: communicating knowledge management benefits to the employees, embedding the knowledge management process in business strategy, developing a system to manage explicit and tacit knowledge, rewarding the sharing of knowledge and at the same time creating a communication methodology within employees, using a suitable IT-based system to support knowledge management and dedicating suitable staff to lead the knowledge management initiatives.

\section{Knowledge Measurement}

Bontis (1999) indicated that knowledge measurement is problematic due to the vague nature of knowledge in general and tacit knowledge in specific. Hong Pew, David and Phil (2008) argued that any discussion concerning knowledge measurement must be linked to intellectual capital that is defined as knowledge and experience that can be transformed into assets or competitive advantage for the organization. Kannan and Aulbur (2004) indicated that the concept of intellectual capital can be measured from two perspectives within the organization:

i- Internal perspective in which the organization is trying to locate the intellectual capital within its employees in order to utilize it more effectively as well as convince top management of its benefits.

ii- External perspective shows that the organizational book value does not take into consideration the organization's intellectual capital assets and only evaluates its physical assets. 
Carson, Ranzijn, Winefield and Marsden (2004) proposed four knowledge measurement methods: financial, intellectual capital, human capital and performance.

\section{Financial Methods}

There are four financial methods that are used to evaluate an organization's intellectual capital. Tobin's Q method established by James Tobin (1969) which evaluates tangible assets not by their book value but by their replacement cost (Luthy, 1998). Economic Value Added (EVA) developed by Stewart (1994) which applies 164 adjustments to the organization's balance sheet in order to get the intellectual capital value. Human Resource Accounting (HRA) developed by Hermanson (1964) which uses the corporate financial data to evaluate human resource assets. Value Creation Intellectual Coefficient (VAIC) was first introduced by Pulic (2000) and it measures the efficiency of utilization of intellectual capital in order to generate profits for the organization (Hejase, Hejase, Tabsh \& Chalak, 2016).

\section{$\underline{\text { Intellectual Capital Methods }}$}

The Chartered Institute of Management Accountants (CIMA, 2003) indicated that intellectual capital can be classifies into three groups: human, structural and relational (Hejase et al., 2016). Wang, 2011 and Carson et al., (2004) stated that Human Capital (HC) is a combination of skills and abilities that are a major factor in the organization's innovation ability such as the competitive advantage. This type of capital belongs to the employees themselves and is lost upon the employees' departure from the organization. Structural Capital (SC) is represented by the organization's physical resources such as the IT infrastructure used by the employees. Structural capital is not lost upon the employees' departure from the organization.

\section{$\underline{\text { Human Capital Methods }}$}

The Human Capital view is one of the most realistic and accurate structures of intellectual capital. Norton (2001) proposed the Human Capital Readiness (HCR) model, which used a modified balance scorecard with an emphasis on human capital (Ingham, 2007). Skyrme (2003) stated that the Human Capital Readiness model evaluates five areas in the human capital: "strategic skills and competencies, leadership, culture and strategic awareness, alignment of goals and incentives, and strategic integration and learning." The HR consultants at Watson Wyatt created the Human Capital Index in 2001. They highlighted the impact of HR dimensions on the increase of human capital and it affects the financial value of the organization. The main advantage of this model is its ability to measure the level of the individual's human capital.

\section{$\underline{\text { Performance Methods }}$}

Carrillo, Robinson, Al-Ghassani and Anumba (2003) adopted the view of measuring knowledge by measuring its impact after being implemented. Andreeva and Kianto, (2012) noted that knowledge management implementation is linked to better performance in organizations. Khalifa, Yu and Shen (2008) argued that the more the employees are using knowledge management systems, the easier it will be for organizations to take corrective actions to fix the issues that are affecting their performance.

Huang, Chen and Yieh (2007) proposed three knowledge management performance methods: quantitative, qualitative and balanced scoreboard methods. Quantitative methods use stock price; return on investment and other financial data from the organization's financial statements. Feng, Chen and Liou (2004) concluded that knowledge management implementation leads stabilizing financial performance while Chang Lee, Lee and Kang (2005) suggested a relationship between company stock price and the successful implementation of knowledge management. Qualitative methods use surveys and questionnaires to measure performance variation which could be subjective and dependent on individuals' opinions (Kannan \& Aulbur, 2004). Balanced Scorecard method, developed by Kaplan and Norton (1996), uses a mixture of financial and non-financial measures. This method is a systematic procedure using indicators of performance to evaluate four categories of performance: financial, internal business processes, consumer, and growth. 


\section{Business Performance}

Carrillo et al., (2000) concluded an exhaustive survey of construction companies and this led to their proposition that knowledge management has to be combined with the firm's key performance indicators and other performance measures such as balanced scorecard to fulfill the need to evaluate the likely benefits of applying knowledge management. Robinson et al., (2004) introduced the main building blocks for Improving Management Performance through Knowledge Transformation (IMPaKT). The framework is composed of three categories. The first category defines the firm's business goals and strategic objectives. The second and third categories assess the firm's knowledge management process and evaluate the implications and the gaps from the people and product perspectives as well as its impact on business performance.

\section{THEORETICAL FRAMEWORK AND RESEARCH DESIGN}

The model that will be used in this study was previously used by Gold et al., (2001). Knowledge Infrastructure Capability consists of three groups: technology, structure of the organization, and culture of the employees (Gold et al., 2001). Knowledge Process Capability has four processes: knowledge acquisition, knowledge conversion, knowledge application and knowledge protection (Gold et al., 2001). When it comes to measuring the organization's performance, Hansen and Oetinger (2001) advocated for using the financial perspective such as, reduction in project cost, sales volume and net profit.

\section{Knowledge Infrastructure Capability}

As per Gold et al., (2001), knowledge infrastructure capability has three groups: technology which is the infrastructure (i.e., internet and intranet) that facilitates and integrates knowledge and information and knowledge in the organization. Structure of the organization (i.e., procedures, rules and document management) which can facilitate and promote knowledge sharing. Culture of the employees (i.e., openness, trust and collaboration) which can affect knowledge management by employee interaction, meetings and communication.

\section{Technology}

Becerra-Fernandez (2000) argued that knowledge-based software supports knowledge management. For example, some of the knowledge-based software used in construction companies is for drawings (e.g., AutoCAD), monitoring the project time and budgeting and resource management (e.g., Primavera). The use of internet and emails is essential for day to day activities especially when the project location is geographically far from the company's main office.

\section{Structure of the Organization}

Mintzberg (1979) defined the organizational structure as "ways to divide work into tasks within the organization with the presence of coordination between different departments". Miles and Snow (1978) indicated that the organizational structure filters the information received by the company and specifies what can be learned from this information. Miller (1987) argued that the organizational structure affects information flow as well as employee interaction. Lei and Slocum (1992) and Kanter (1994) proposed that the horizontal organizational form facilitates knowledge transfer within the firm. In construction companies, the project structure represents the information flow within the project. As per Tserng and Li (2004), there are six management stages in construction companies: problem happening, create knowledge, share knowledge, record knowledge, knowledge storage and knowledge reuse (Kanapeckiene, Kaklauskas, Zavadskas \& Seniut, 2010).

\section{Culture}

Ajmal and Koskinen (2008) argued that the organizational culture is based on assumptions based on deep beliefs of the organization's participants as well as the demonstration of these beliefs by actions and reactions of the participants. Ajmal and Koskinen, (2008) referred the failure in knowledge transfer to the cultural factors rather than the technological reasons. DeTiene and Jackson (2001) argued that the organizational culture could be a major cause of failure for the knowledge management process. Bedford (2013) stated that the role of individuals could potentially 
come into conflict with the company culture. In order to avoid this conflict, Kayworth and Leidner (2003) proposed that sharing knowledge through interpersonal relationships must be encouraged by the organizational culture to ensure successful knowledge creation, storage, transfer and application. Building a supportive organizational culture is vital for a successful knowledge management system.

\section{Knowledge Process Capability}

Kayworth and Leidner (2003) suggested that Knowledge Process Capability has four categories. Knowledge acquisition which includes creating and collaborating knowledge. Knowledge conversion which includes organizing, storing, integrating and combining knowledge. Knowledge application which includes retrieving and sharing knowledge. Knowledge protection which includes securing knowledge within the organization.

\section{Knowledge Acquisition}

Knowledge acquisition can be considered to have two levels, organizational and individual. Liao, Wang, Chuang, Shih and Liu (2010) defined knowledge acquisition at the organizational level as "accepting knowledge from outside the organizational environment, transforming it and using it". Gray and Meister (2004) defined knowledge acquisition at the individual level as the changing of the mental model of the individual by changing their beliefs to the new acquired knowledge with the intention of using this knowledge in order to be effective (Pemsel \& Müller, 2012).

\section{Knowledge Conversion}

The knowledge conversion is a continuous transformation from tacit to explicit knowledge and vice versa (Nonaka, 1994). According to Nonaka (1994) and Nonaka and Takeuchi (1995), knowledge conversion has four stages: socialization, externalization, combination and internalization. Socialization can be viewed as the conversion of tacit knowledge into other forms of tacit knowledge using social interactions. Externalization can be viewed as the conversion of tacit knowledge to explicit knowledge. Combination can be viewed as the conversion of explicit knowledge into other forms of explicit knowledge using sorting and modeling. Internalization can be viewed as the conversion of explicit knowledge to tacit knowledge within the individual by learning and application.

\section{Knowledge Application}

According to Newell, Huang, Galliers and Pan (2003) knowledge application is used to enhance the business strategy, solve the problems that arise due to new projects, reduce the cost and the execution time of similar projects by using previous projects' reports, lessons learned and closed out reports. Knowledge transfer is the movement of knowledge to where it can be easily accessed and reused.

\section{Knowledge Protection}

Khamseh and Jolly (2008) defined knowledge protection as blocking the knowledge sharing in the knowledge management system. Jennex and Durcikova (2013) defined knowledge protection as preventing the leakage of knowledge to unauthorized external users as well as preventing tacit knowledge loss due to employee turnover. Dhillon and Torkzadeh (2006) argued that organizations rely on information technology systems to secure their knowledge against commercial unauthorized use. Ahmad, Bosua and Scheepers (2014) stated that poor knowledge protection could cause financial losses for the organization as well as productivity losses.

\section{Organization Performance}

The traditional method to measure company performance is from financial perspective such as reduction in project cost, increase in sales volume and increase in net profits. Chakravarthy (1986) found that using financial methods to measure the business performance could give misleading results about the continuity of the company competitive advantage and innovation. Fliaster (2004) suggested using other intangible methods such as, consumer satisfaction perspective, learning and growth perspective, supplier perspective and internal processes perspective. Tseng and Fang, 2015 and Maltz, Shenhar and Reilly (2003) proposed using financial and non-financial measures such as the following five indexes financial, consumer, process, people development and future. 
Hypothesis 1: The knowledge infrastructure capability (KIC) has a positive effect on business performance (BP).

Hypothesis 2: The knowledge process capability (KPC) has a positive effect on business performance (BP).

\section{DATA COLLECTION}

Following the data collection method used in Perng and Chang (2004), the authors contacted the Egyptian Federation for Construction and Building Contractors, the following data was received as of August 2015: total number of construction companies in Egypt was 10,622 companies. Total number of construction companies classified as First Class (companies allowed to take unlimited integrated projects) was 380 companies. Number of construction companies classified as first class in Cairo, Giza and Alexandria governorates was 299 companies. The authors choose to focus on first class construction companies in Egypt as they are all working within the same culture, same project conditions and same Human Resources mindset.

The questionnaires were distributed to senior managers with 15 years or more of experience in construction who have been working for the past 5 years in the same company. The senior managers included project managers, construction managers, general managers, HR managers and contract managers. The questionnaires were randomly distributed to senior managers in 146 of the 299 first class construction companies in Cairo, Giza and Alexandria governorates. The final sample size was 75 first class construction companies which is about a $51 \%$ response rate.

The proposed questionnaire was modified from the one previously used by Gold et al., (2001) and Smith (2006). The proposed questionnaire includes eight sections. The first three sections measure the Knowledge Infrastructure Capability including technology, company structure and culture (Ghosh \& Scott, 2009). The following four sections measure Knowledge Process Capability including knowledge acquisition, knowledge conversion, knowledge application and knowledge protection (Emadzade, Mashayekhi \& Abdar, 2012). The last section measures the company performance from the following perspectives: financial, consumer, learning and growth, supplier and internal processes. Responses were presented using a 5 -scale Likert scale with a range from 1 (strongly disagree) to 5 (strongly agree). At the beginning of the questionnaire the authors included four questions regarding the organization's legal status, sector, number of employees in 2015 and the availability of a training and development plans. The questionnaire is available in Appendix A.

\section{METHODOLOGY AND RESULTS}

\section{Descriptive Statistics}

Table 1 shows that $65.3 \%$ of the organizations in the sample are partnerships, $29.3 \%$ are limited liability, and $5.3 \%$ are sole proprietorships. $89.3 \%$ are private organizations and $10.7 \%$ are public sector organizations. Sixty one point three percent of the organizations in the sample have in excess of 100 employees, $17.3 \%$ have between 50 and 99 employees and $21.3 \%$ have between 5 and 49 employees. Finally, $78.7 \%$ of the organizations have training and development plans. 
Table 1. Sample Descriptive Statistics

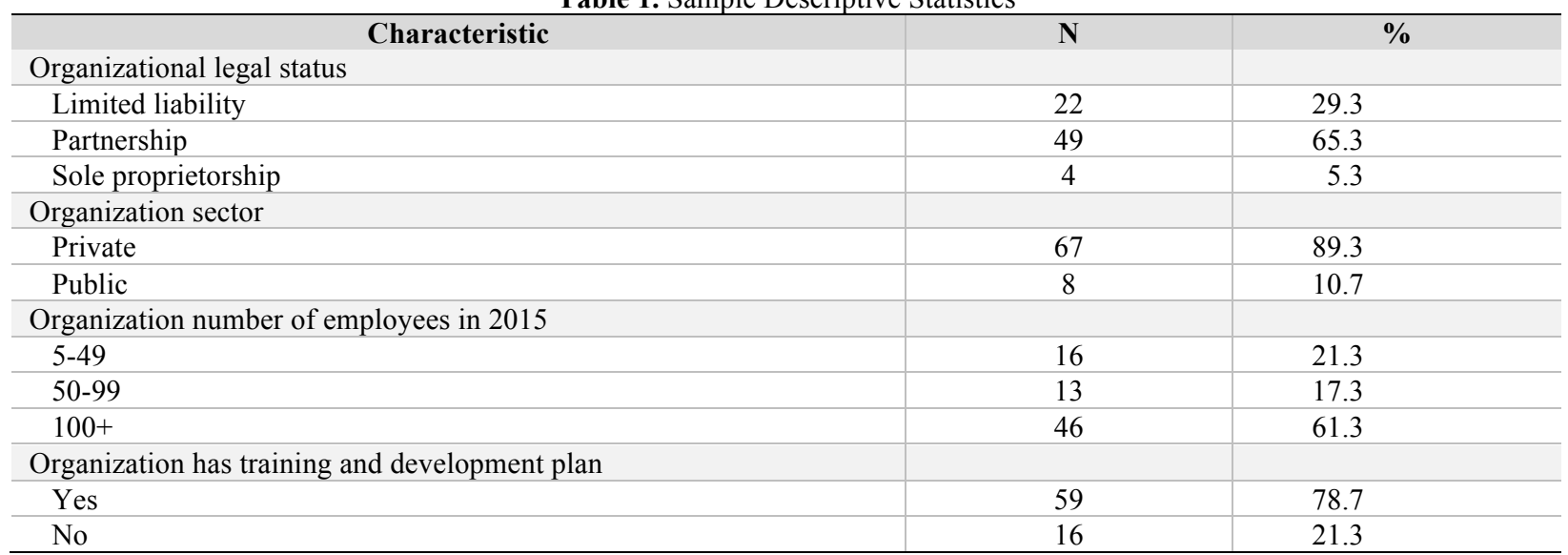

Panel A of Table 2 shows the categorization of the variables that were computed from the survey questions in Appendix A. These variables are KIC (Knowledge Infrastructure Capability), KPC (Knowledge Process Capability) and BP (Business Performance) (Cho \& Korte, 2014). Panel B of Table 2 shows the descriptive statistics for these three variables (KIC, KPC and BP). The descriptive statistics for the individual items are provided in Appendix B (Lu, 2014). Panel $\mathrm{C}$ of Table 2 shows the results of the normality tests for the three variables. The normality assumption is accepted for all three variables according to the Shapiro-Wilk test. Panel D of Table 2 shows that KIC and KPC are both positively correlated with BP with Pearson's correlation 0.663 and 0.664 , respectively.

Table 2. Categorization, Descriptive Statistics, Normality Tests and Correlations for KIC, KPC and BP

\begin{tabular}{|c|c|c|c|}
\hline \multicolumn{4}{|c|}{ Panel A. Variables Measured by Questionnaire } \\
\hline Variable Type & Variable Name & Independent Variable Break down & Questionnaire Item Number \\
\hline \multirow{7}{*}{ Independent } & \multirow{3}{*}{$\begin{array}{c}\text { Knowledge Infrastructure } \\
\text { Capability }\end{array}$} & Technology & $\begin{array}{c}\text { TI } \\
1,2,3,4\end{array}$ \\
\hline & & Structure & $\begin{array}{c}\text { SI } \\
1,2,3,4,5,6,7\end{array}$ \\
\hline & & Culture & $\begin{array}{c}\text { CI } \\
1,2,3,4,5,6\end{array}$ \\
\hline & \multirow{4}{*}{$\begin{array}{l}\text { Knowledge Process } \\
\text { Capability }\end{array}$} & Acquisition & $\begin{array}{c}\text { AP } \\
1,2,3,4,5,6\end{array}$ \\
\hline & & Conversion & $\begin{array}{c}\mathrm{CP} \\
1,2,3,4,5,6\end{array}$ \\
\hline & & Application & $\begin{array}{c}\mathrm{AP} \\
1,2,3,4,5,6,7\end{array}$ \\
\hline & & Protection & $\begin{array}{c}\mathrm{PP} \\
1,2,3,4,5,6,7\end{array}$ \\
\hline \multirow{5}{*}{ Dependent } & \multirow{5}{*}{ Business Performance } & Financial perspective & $\begin{array}{c}\mathrm{BP} \\
1,2,3\end{array}$ \\
\hline & & Consumer perspective & $\begin{array}{c}\mathrm{BP} \\
4,5,6\end{array}$ \\
\hline & & Learning \& Growth perspective & $\begin{array}{c}\text { BP } \\
7,8,9,10\end{array}$ \\
\hline & & Supplier perspective & $\begin{array}{c}\mathrm{BP} \\
11,12\end{array}$ \\
\hline & & Internal processes & $\begin{array}{c}\mathrm{BP} \\
13,14\end{array}$ \\
\hline
\end{tabular}

(Table 2, Panel B continued on next page) 
(Table 2 continued)

\begin{tabular}{|c|c|c|c|c|}
\hline \multicolumn{5}{|c|}{ Panel B. Descriptive Statistics for KIC, KPC and BP } \\
\hline Variable & $\mathbf{N}$ & Mean & SD & Range \\
\hline KIC score & 73 & 59.92 & 11.47 & $32-83$ \\
\hline KPC score & 74 & 90.44 & 18.17 & $41-130$ \\
\hline BP score & 72 & 48.93 & 9.63 & $21-70$ \\
\hline
\end{tabular}

Panel C. Normality Test

\begin{tabular}{|c|c|c|c|}
\hline & \multicolumn{3}{|c|}{ Shapiro-Wilk } \\
\hline & \multicolumn{2}{|l|}{ Statistic } & df \\
\hline KIC score & \multicolumn{2}{|l|}{0.972} & 75 \\
\hline KPC score & 0.987 & & 75 \\
\hline BP score & 0.990 & & 75 \\
\hline \multicolumn{4}{|c|}{${ }^{*} \mathrm{p}<0.05, * * \mathrm{p}<0.01, * * * \mathrm{p}<0.001$} \\
\hline \multicolumn{4}{|c|}{ Panel D. Correlation between KIC, KPC and BP } \\
\hline Scale & KIC score & KPC score & BP score \\
\hline KIC score & 1 & & \\
\hline KPC score & 0.875 & 1 & \\
\hline BP score & 0.663 & 0.664 & 1 \\
\hline
\end{tabular}

\section{Bivariate Analysis}

The authors use one-way ANOVA to test for differences in the means between the different categories of organization legal status and organization size. Panel A of Table 3 shows the mean for the three variables KIC, KPC and BP based on the organization's legal status (Trussel \& Patrick, 2012). Panel B of Table 3 shows that none of the three types of organization legal status differ in terms of KIC, KPC or BP. Panel C of Table 3 shows the mean for the three variables KIC, KPC and BP based on the organization size (Keung \& Shen, 2013). Panel D of Table 3 shows that there are no significant differences between different company sizes in KIC, KPC or BP.

Table 3. Means and One-Way ANOVA for KIC, KPC and BP across Organizational Legal Status and Organization Size

\begin{tabular}{|c|c|c|c|c|}
\hline \multicolumn{5}{|c|}{ Panel A. Averages by Organization Legal Status } \\
\hline \multicolumn{2}{|c|}{ Organization legal status } & KIC score & KP score & BP score \\
\hline \multirow{3}{*}{ Limited liability } & Mean & 60.86 & 90.41 & 49.64 \\
\hline & $\mathrm{N}$ & 22 & 22 & 22 \\
\hline & SD & 9.949 & 15.849 & 6.630 \\
\hline \multirow{3}{*}{ Partnership } & Mean & 59.49 & 90.78 & 48.57 \\
\hline & $\mathrm{N}$ & 49 & 49 & 49 \\
\hline & SD & 12.322 & 19.651 & 11.107 \\
\hline \multirow{3}{*}{ Sole proprietorship } & Mean & 60.00 & 86.50 & 49.50 \\
\hline & $\mathrm{N}$ & 4 & 4 & 4 \\
\hline & SD & 10.646 & 13.379 & 1.000 \\
\hline
\end{tabular}

Panel B. One-Way ANOVA: Differences across Organizational Legal Status

\begin{tabular}{|c|c|c|c}
\hline \multicolumn{1}{|c|}{ Scale } & SS & df & F statistic \\
\hline KIC score & & 2 & 0.106 \\
\hline Between groups & 28.68 & 72 & \\
\hline Within groups & 9706.84 & 2 & 0.100 \\
\hline KPC score & & 72 & \\
\hline Between groups & 24348.85 & & 0.098 \\
\hline Within groups & & 2 & \\
\hline BP score & 18.58 & 72 & \\
\hline Between groups & 6848.09 & & \\
\hline Within groups & & & \\
\hline
\end{tabular}

$* \mathrm{p}<0.05, * * \mathrm{p}<0.01, * * * \mathrm{p}<0.001$

(Table 3, Panel C continued on next page) 
(Table 3 continued)

\begin{tabular}{|c|c|c|c|c|}
\hline \multicolumn{5}{|c|}{ Panel C. Averages by Organization Size } \\
\hline Numbe & & KIC score & KPC score & BP score \\
\hline \multirow{3}{*}{$5-49$} & Mean & 58.63 & 85.38 & 49.31 \\
\hline & $\mathrm{N}$ & 16 & 16 & 16 \\
\hline & SD & 12.748 & 18.736 & 9.090 \\
\hline \multirow{3}{*}{$50-99$} & Mean & 62.08 & 91.69 & 49.00 \\
\hline & $\mathrm{N}$ & 13 & 13 & 13 \\
\hline & SD & 13.357 & 21.700 & 10.855 \\
\hline \multirow{3}{*}{$100+$} & Mean & 59.76 & 91.85 & 48.78 \\
\hline & $\mathrm{N}$ & 46 & 46 & 46 \\
\hline & SD & 10.613 & 16.982 & 9.672 \\
\hline
\end{tabular}

Panel D. One-Way ANOVA: Differences across Organizational Size

\begin{tabular}{|c|c|c|c|}
\hline Scale & SS & df & F statistic \\
\hline \multicolumn{4}{|l|}{ KIC score } \\
\hline Between groups & 88.48 & 2 & 0.330 \\
\hline Within groups & 9647.04 & 72 & \\
\hline \multicolumn{4}{|l|}{ KPC score } \\
\hline Between groups & 522.026 & 2 & 0.786 \\
\hline Within groups & 23894.45 & 72 & \\
\hline \multicolumn{4}{|l|}{ BP score } \\
\hline Between groups & 3.40 & 2 & 0.018 \\
\hline Within groups & 6863.26 & 72 & \\
\hline
\end{tabular}

The authors use t-tests to examine the differences in the means for the organization sector and the availability of training and development plans. Panel A of Table 4 shows there are no statistically significant differences between private and public organizations in any of the three studied dimensions. Panel B of Table 4 shows that organizations having training and development plans will have statistically significant higher KIC, KPC and BP scores than organizations with no training and development plans.

Table 4. T-test for KIC, KPC and BP across Organizational Sector and Organizations with Training and Development Plans Panel A. T-test: Differences across Organizational Sector

\begin{tabular}{|l|c|c|c|c|c|c} 
& $\begin{array}{c}\text { Organization } \\
\text { sector }\end{array}$ & N & Mean & SD & T statistic & df \\
\hline \multirow{2}{*}{ KIC score } & Private & 67 & 60.03 & 10.946 & 0.238 & 73 \\
\hline \multirow{2}{*}{ KPC score } & Public & 8 & 59.00 & 16.125 & & 73 \\
\hline \multirow{2}{*}{ BP score } & Private & 67 & 90.91 & 17.133 & 0.460 & 73 \\
\hline$* \mathrm{*}<0.05 * * \mathrm{p}<0.01, * * * \mathrm{p}<0.001$ & Public & 8 & 86.50 & 26.468 & & 1.426 \\
\hline
\end{tabular}

$* \mathrm{p}<0.05, * * \mathrm{p}<0.01, * * * \mathrm{p}<0.001$

Panel B. T-test: Differences between Organization with Training and Development Plans

\begin{tabular}{l|c|c|c|c|c|c|}
\hline & $\begin{array}{c}\text { Organization has training } \\
\text { and development plan }\end{array}$ & $\mathbf{N}$ & Mean & SD & T statistic & df \\
\hline \multirow{2}{*}{ KIC score } & Yes & 59 & 62.47 & 10.149 & $4.076^{* * *}$ & 73 \\
\hline \multirow{2}{*}{ KPC score } & No & 16 & 50.50 & 11.419 & \\
\hline & Yes & 59 & 92.85 & 16.623 & $2.265^{*}$ & 73 \\
\hline BP score & No & 16 & 81.56 & 21.270 & & 73 \\
\hline & Yes & 59 & 50.69 & 8.889 & $3.229^{* *}$ & 73 \\
\hline
\end{tabular}

${ }^{* p}<0.05, * * \mathrm{p}<0.01,{ }^{* * *} \mathrm{p}<0.001$ 


\section{Regression Analysis}

The authors conducted Ordinary Least Square (OLS) Regressions with BP score as the dependent variable, KIC score as the independent variable in Table 5 (McCall, Arnold \& Sutton, 2008) and KPC score as the independent variable in Table 6 (Good, Aggleton, Kentridge, Barker \& Neave, 1997). "Organization has training and development plan" was used as a control variable in Tables 5 and 6 . In Table 5 the estimated coefficient of the KIC score is positive and significant as predicted in hypothesis 1 which indicated that there is a positive association between KIC and the company performance.

Table 5. OLS Regression Estimates for Hypothesis 1: The knowledge infrastructure capability (KIC) has a positive effect on business performance (BP) ( $\mathrm{t}$ statistics in brackets)

\begin{tabular}{|c|c|}
\hline & BP score \\
\hline \multirow[b]{2}{*}{ Constant } & 15.833 \\
\hline & $(3.513)^{* * *}$ \\
\hline \multirow{2}{*}{ KIC score } & 0.527 \\
\hline & $(6.452)^{* * *}$ \\
\hline \multirow{2}{*}{ Organization has training and development plan } & 1.949 \\
\hline & $(0.858)$ \\
\hline Adjusted $\mathrm{R}^{2}$ & $43 \%$ \\
\hline VIF & 1.228 \\
\hline White-Koenker & 12.698 \\
\hline
\end{tabular}

In Table 6 the estimated coefficient of the KPC score is positive and significant as predicted in hypothesis 2 which indicated that there is a positive association between KPC and the company performance. The control variable "Organization has training and development plan" is also positive and significant indicating that companies with training and development plans have higher performance compared to companies with no such plans. The variance inflation factors (VIF) in Tables 5 and 6 are less than 10, as result there are no signs of multicollinearity. The WhiteKoenker statistics given in the last line of the Tables 5 and 6 show that all of our regressions are free of heteroscedasticity (Baum, Schaffer \& Stillman, 2003).

Table 6. OLS Regression Estimates for Hypothesis 2: The knowledge process capability (KPC) has a positive effect on business performance (BP) (t statistics in brackets)

\begin{tabular}{|c|c|}
\hline & BP score \\
\hline \multirow{2}{*}{ Constant } & 15.901 \\
\hline & $(4.204)^{* * *}$ \\
\hline \multirow{2}{*}{ KPC score } & 0.325 \\
\hline & $(6.956)^{* * *}$ \\
\hline \multirow{2}{*}{ Organization has training and development plan } & 4.586 \\
\hline & $(2.226)^{*}$ \\
\hline Adjusted $\mathrm{R}^{2}$ & $46.2 \%$ \\
\hline VIF & 1.070 \\
\hline White-Koenker & 13.804 \\
\hline
\end{tabular}

\section{DISCUSSION, IMPLICATIONS AND CONCLUSIONS}

The objective of this study was to assess the effectiveness of knowledge management systems within the Egyptian construction industry from the perspective of Knowledge Infrastructure Capability (KIC), Knowledge Process Capability (KPC) and their impact on Business Performance (BP) from financial, consumer, learning and growth, supplier and internal perspectives. Our results indicate that the organizational knowledge management capabilities do affect business performance. 
There are statistically significant differences in KIC scores with organizations having training and development plans showing a higher score compared to those that do not have such plan (62.5 vs. 50.5). Organizations having training and development plans also have significantly higher KPC scores compared to those that do not have such plan (92.9 vs. 81.6). Organizations with training and development plans also show significantly higher performance compared to those that do not have such plans (50.7 vs. 42.4). KIC and KPC are both positively correlated with BP with Pearson's correlation 0.663 and 0.664 , respectively.

\section{Implications}

Eighty percent of the organizations in our sample claimed to have training and development plans, while the remaining $20 \%$ did not have well developed training plans. It is important for top management in the construction industry in Egypt to realize the expected positive effects of implementing well developed training and development plans on business performance. This will hopefully lead Egyptian construction companies to invest more in training and development plans of their employees.

Based on our study's results, it is highly recommended that management encourages knowledge transfer within the same organization. Also the application of a reward system directly related to knowledge exchange between departments may positively affect knowledge management in Egyptian construction companies. The rotation of employees between different departments might lead to a better application of the knowledge management system. Finally, continuous monitoring of knowledge management systems in Egyptian construction companies, as well as, the use of benchmarking with industry leaders is essential for better business performance.

\section{Future Research}

Future research could focus on the effect of employee turnover and its impact on the successful application of knowledge management in Egyptian construction companies. Future studies can focus on small and medium size Egyptian construction companies. These companies are more flexible to change and can be restructured more easily. More examination is required for the barriers to knowledge exchange within organizations which will help give a realistic corrective action plan for companies planning to maximize their performance by applying knowledge management system.

\section{Limitations}

One of the limitations for the study is that the questionnaire respondents may be biased but there are no means for an ideal method for data collection. Another limitation is that the survey participants are answering the questionnaire from their perception, as it was not possible to check the documents of the surveyed companies. Another limitation of the study was the translation of the questionnaires from English to Arabic then back to English. The authors tried to overcome this limitation by using the Werner and Campbell (1970), decentring method.

The authors attempt to reduce the selection bias issue (Heckman, 1979) by randomly selecting 146 of the 299 first class construction companies in Cairo, Giza \& Alexandria governorates. The sample used construction companies classified as first class according to the Egyptian Federation for Construction \& Building Contractors on August 2015 in Cairo, Giza and Alexandria. To include construction companies in other governorates and other classes will be a time consuming and costly process. The problem is that the results of the study cannot be generalized to all construction companies in Egypt.

\section{AUTHOR BIOGRAPHIES}

Ahmed Elfar is a DBA student at ESLSCA International Business School, Cairo, Egypt. He is also the Projects Director at the Pioneer Holding, Co. in Cairo, Egypt.

Abdel Moneim Elsaid is a Full Professor of Management at the Faculty of Commerce, Ain Shams University, Cairo, Egypt. He has published in Journal of Applied Business Research, Research \& Practice in Human Resource Management and International Journal of Electronic Marketing \& Retailing. 
Eahab Elsaid is an Associate Professor of Finance at the Odette School of Business, University of Windsor, Canada. He has published in Journal of Applied Business Research, Gender in Management: An International Journal, Quarterly Review of Economics \& Finance and Managerial Finance.

\section{REFERENCES}

Ahmad, A., Bosua, R., \& Scheepers, R. (2014). Protecting organizational competitive advantage: a knowledge leakage perspective. Computers \& Security, 42, 27-39.

Ajmal, M., \& Koskinen, K. (2008). Knowledge transfer in project-based organizations: an organizational culture perspective. Project Management Journal, 39(1), 7-15.

Al-Adaileh, R., \& Al-Atawi, M. (2011). Organizational culture impact on knowledge exchange: Saudi telecom context. Journal of Knowledge Management, 15(2), 212-230.

Alavi, M., \& Leidner, D. (2001). Review: knowledge management and knowledge management systems: conceptual foundations and research issues. MIS Quarterly, 25(1), 107-136.

Al-Hawamdeh, S. (2002). Knowledge management: re-thinking information management and facing the challenge of managing tacit knowledge. Information Research, 8(1), paper no. 143. Retrieved from: http://InformationR.net/ir/81/paper143.html

Andreeva, T., \& Kianto, A. (2012). Does knowledge management really matter? Linking knowledge management practices, competitiveness and economic performance. Journal of Knowledge Management, 16(4), 617-636.

Baum, C., Schaffer, M. \& Stillman, S. (2003). Instrumental variables and GMM: estimation and testing. Stata Journal, 3, 1-31.

Becerra-Fernandez, I. (2000). The role of artificial intelligence technologies in the implementation of people-finder knowledge management systems. Knowledge Based Systems, 13(5), 315-20.

Bedford, D. (2013). A case study in knowledge management education - historical challenges and future opportunities. The Electronic Journal of Knowledge Management, 11(3), 199-213.

Bontis, N. (1999). Managing organizational knowledge by diagnosing intellectual capital:framing and advancing the state of the field. International Journal of Technology Management, 18(5-8), 433-462.

Carrillo, P., Robinson, H., Al-Ghassani, A., \& Anumba, C. (2004). Knowledge management in UK construction: strategies, resources and barriers. Project Management Journal, 35(1), 46-56.

Carson, E., Ranzijn, R., Winefield, A., \& Marsden, H. (2004). Intellectual capital: mapping employee and work group attributes. Journal of Intellectual Capital, 5(3), 443-463.

Chang Lee, K., Lee, S., \& Kang, I. (2005). KMPI: measuring knowledge management performance. Information \& Management, 42(3), 469-482.

Chakravarthy, B. (1986). Measuring strategic performance. Strategic Management Journal, 7(5), 437-458.

Chen, C., \& Huang, J. (2007). How organizational climate and structure affect knowledgemanagement - the social interaction perspective. International Journal of Information Management, 27(2), 104-118.

Chen, L., \& Mohamed, S. (2005). Conceptual model linking knowledge management with organizational performance. In Ribeiro, F., Love, P., Davidson, C., Egbu, C., \& Dimitrijevic, B. (Eds), In the Proceedings of the CIB W102-2005 Meeting and International Conference: Information and Knowledge Management in a Global Economy, Lisbon, Portugal, 415-423.

Cheng, E., Li, H., \& Love, P. (2000). Establishment of critical success factors for construction partnering. Journal of Management in Engineering, 16(2), 84-92.

Cho, T., \& Korte, R. (2014). Managing knowledge performance: testing the components of a knowledge management system on organizational performance. Asia Pacific Education Review, 15(2), 313-327.

CIMA (Chartered Institute of Management Accountants). (2003). Understanding corporate value: managing and reporting intellectual capital. Retrieved from http://www.cimaglobal.com/Documents/ImportedDocuments/tech_techrep_understanding_corporate_value_2003.pdf

Davenport, T., \& Prusak, L. (2000). Working knowledge: How organizations manage what they know. Boston, $\overline{M A}$ : Harvard Business School Press.

DeTiene, K., \& Jackson, L. (2001). Knowledge management: understanding theory and developing strategy. Competitiveness Review, 11(1), 1-11.

Dhillon, G., \& Torkzadeh, G. (2006). Value-focused assessment of information system security in organizations. Information Systems Journal, 16(3), 293-314.

Emadzade, M., Mashayekhi, B., \& Abdar, E. (2012). Knowledge management capabilities and organizational performance. Interdisciplinary Journal of Contemporary Research in Business, 3(11), 781.

Feng, K., Chen, E., \& Liou, W. (2004). Implementation of knowledge management systems and firm performance: an empirical investigation. Journal of Computer Information Systems, 45(2), 92-104.

Fliaster, A. (2004). Cross-hierarchical interconnectivity: forms, mechanisms and transformation of leadership culture. Knowledge Management Research \& Practice, 2(1), 48-57. 
Ghosh, B., \& Scott, J. (2009). Managing clinical knowledge among hospital nurses. International Journal of Technology Management, 47(1), 57-74.

Gold, A., Malhotra, A., \& Segars, A. (2001). Knowledge management: an organizational capabilities perspective. Journal of Management Information Systems, 18(1), 185-214.

Good, J., Aggleton, J., Kentridge, R., Barker, J., and Neave, N., (1997). Measuring musical aptitude in children: on the role of age, handedness, scholastic achievement, and socioeconomic status. Psychology of Music, 25(1), 57-69.

Grace, T. (2009). Wikis as a knowledge management tool. Journal of Knowledge Management, 13(4), 64-74.

Grant, K. (2007), Tacit knowledge revisited - we can still learn from Polanyi. The Electronic Journal of Knowledge Management, 5(2), 173-180.

Gray, P., \& Meister, D. (2004). Knowledge sourcing effectiveness. Management Science, 50(6), 821-834.

Hansen, M., \& Oetinger, B. (2001). Introducing T-shaped managers: knowledge management's next generation. Harvard Business Review, March, 106-116.

Heckman, J. (1979). Sample selection bias as a specification error. Econometrica, 47(1), 153-161.

Hejase, H., Hejase, A., Tabsh, H., and Chalak, H. (2016). Intellectual capital: an exploratory study from Lebanon. Open Journal of Business and Management, 4(4), 571-605.

Hermanson, R. (1964). Accounting for human assets. East Lansing: MI: Michigan State University Press.

Hong Pew, T., David, P., \& Phil, H. (2008). The evolving research on intellectual capital. Journal of Intellectual Capital, 9(4), 585-608.

Huang, M., Chen, M., \& Yieh, K. (2007). Comparing with your main competitor: the single most important task of knowledge management performance measurement. Journal of Information Science, 33(4), 416-434.

Ingham, J. (2007). Managing and measuring human capital. In Ingham, J. (Eds), In Strategic Human Capital Management: Creating Value through People, Taylor and Francis, 167-204.

Jennex, M., \& Durcikova, A. (2013). Assessing knowledge loss risk. $201346^{\text {th }}$ Hawaii International Conference on System Sciences (HICSS), Wailea, Maui, HI, USA, 3478-3487. Retrieved from: http://ieeexplore.iee.org/xpl/articleDetails.jsp?arnumber=6480264\&sortType\%3Dasc_Sequence\%26filter\%3DAND \%28p_IS_Number\%3A6479821\%29\%26pageNumber\%D18

Kannabiran, G., \& Pandyan, C. (2010). Enabling role of governance in strategizing and implementing KM. Journal of Knowledge Management, 14(3), 335-347.

Kannan, G., \& Aulbur, W. (2004). Intellectual capital: measurement effectiveness. Journal of Intellectual Capital, 17(6), 389413.

Kanapeckiene, L., Kaklauskas, A., Zavadskas, E., and Seniut, M. (2010). Integrated knowledge management model and system for construction projects. Engineering Applications of Artificial Intelligence, 23(7), 1200-1215.

Kanter, R. (1994). Collaborative advantage: the art of alliances. Harvard Business Review, 72(4), 96-108.

Kaplan, R., \& Norton, D. (1996). The balanced scoreboard: translating strategy into action. Harvard Business Press.

Kayworth, T., \& Leidner, D. (2003).Organizational culture as a knowledge resource. In Holsapple, C. (Eds.), Handbook on knowledge management 1: knowledge matters, Springer-Verlag, Heidelberg, 235-252.

Keung, C., \& Shen, L. (2013). Measuring the networking performance for contractors in practicing construction management. Journal of Management in Engineering, 29(4), 400-406.

Khalifa, M., Yu, A., \& Shen, K. (2008). Knowledge management systems success: a contingency perspective. Journal of Knowledge Management, 12(1), 119-132.

Khamseh, H., \& Jolly, D. (2008). Knowledge transfer in alliances: determinant factors. Journal of KnowledgeManagement, 12(1), 37-50.

Kidwell, J., Vander Linde, K., \& Johnson, S. (2000). Applying corporate knowledge management practices in higher education: colleges and universities have significant opportunities to apply knowledge management practices to support every part of their mission. Educause Quarterly, 23(4), 28-33.

Lei, D., \& Slocum, J.W. Jr (1992). Global strategy, competence-building and strategic alliances. California Management Review, 35(1), 81-97.

Liao, C., Wang, H., Chuang, S., Shih, M., \& Liu, C. (2010). Enhancing knowledge management for R\&D innovation and firm performance: an integrative view. African Journal of Business Management, 4(14), 3026-3038.

Lindvall, M., Rus, I., \& Sinha, S. (2003). Software systems support for knowledge management. Journal of Knowledge Management, 7(5), 137-150.

Lloria, M. (2008). A review of the main approaches to knowledge management. Knowledge Management Research \& Practice, 6(1), 77-89.

Lu, H. (2014). Does disclosure of non-financial statement information reduce firms' propensity to under-invest? Quarterly Journal of Finance and Accounting, 51(3/4), 1-44.

Luthy, D. (1998). Intellectual capital and its measurement. Proceedings of the Asian Pacific Interdisciplinary Research in Accounting Conference (APIRA), Osaka.

Maier, R., \& Remus, U. (2002). Defining process-oriented knowledge management strategies. Knowledge and Process Management - The Journal of Corporate Transformation, 9(2), 103-118 
Maltz, A., Shenhar, A., \& Reilly, R. (2003). Beyond the balanced scorecard: refining the search for organizational success measures. Long Range Planning, 36(2), 187-204.

McCall, H., Arnold, V., \& Sutton, S. (2008). Use of knowledge management systems and the impact on the acquisition of explicit knowledge. Journal of Information Systems, 22(2), 77-101.

Miles, R., \& Snow, C. (1978). Organizational strategy, structure and process. Academy of Management Review, 3(3), 546-562.

Miller, D. (1987). Strategy making and structure: analysis and implications for performance. Academy of Management Journal, 30(1), 7-32.

Mintzberg, H. (1979). The structuring of organizations. Englewood Cliffs, NJ: Prentice-Hall.

Mohamed, S., \& Anumba, C. (2006). Potential for improving site management practices through knowledge management. Construction Innovation, 6(4), 232-249.

Moteleb, A., \& Woodman, M. (2007). Notions of knowledge management systems: a gap Analysis. The Electronic Journal of Knowledge Management, 5(1), 55-62.

Newell, S., Huang, J., Galliers, R., \& Pan, S. (2003). Implementing enterprise resource planning and knowledge management systems in tandem: fostering efficiency and innovation complementarity. Information andOrganization, 13(1), 25-52.

Nidumolo S., Subramani M., \& Aldrich A. (2005). Situated learning and situated knowledge web: exploring the ground beneath knowledge management. Journal of Management Information System, 18(1), 115-150.

Nonaka, I. (1994). A dynamic theory of organizational knowledge creation. Organization Science, 5(1), 14-37.

Nonaka, I., \& Takeuchi, H. (1995). The knowledge-creating company. How Japanese companies create the dynamics of innovation. Oxford: Oxford University Press.

Norton, D. (2001). Managing the development of human capital. Balanced Scorecard Report, September-October.

Pemsel, S., \& Müller, R. (2012). The governance of knowledge in project-based organizations. International Journal of Project Management, 30(8), 865-876.

Perng, Y., \& Chang, C. (2004). How does government procurement law affect bidding price competition in Taiwan? Building Research \& Information, 32(6), 497-509.

Polanyi, M. (1967). The Tacit Dimension. Chicago, IL: The University of Chicago Press.

Pulic, A. (2000). VAIC - an accounting tool for IC management. International Journal of Technology Management, 20(5-8), 702714.

Ragab, M., \& Arisha, A. (2013), Knowledge management and measurement: a critical review. Journal of Knowledge Management, 17(6), 873-901.

Robinson, H., Carrillo, P., Anumba, C., \& Al-Ghassani, A. (2004). Developing a business case for knowledge management: the IMPaKT approach. Construction Management and Economics, 22(7), 733-743.

Serra, P., Ribeiro, F., \& Grilo, A. (2012). Knowledge management system in a construction company: a case study. eWork and eBusiness in Architecture Engineering and Construction ECPPM 2012.

Scarborough, H., Swan, J., \& Preston, J. (1999). Issues in People Management: Knowledge Management: A Literature Review. Institute of Personnel and Development, The Cromwell Press, Wiltshire.

Shen, Q., \& Liu, G. (2003). Critical success factors for value management studies in construction. Journal of Construction Engineering and Management, 129(5), 485-491.

Skyrme, D. (2003). Measuring knowledge and intellectual capital: models and methods to maximize the value of knowledge, intangibles and intellectual assets. Business Intelligence.

Smith, T. (2006). Knowledge management and its capabilities linked to the business strategy for organizational effectiveness. Published doctoral thesis, Nova Southeastern University, USA.

Stewart, T. (1994). Your company's most valuable asset: intellectual capital. Fortune, October 3, 68-74.

Tobin, J. (1969). A general equilibrium approach to monetary theory. Journal of Money, Credit and Banking, 1(1), 15-29.

Trussel, J., \& Patrick, P. (2012). Predicting significant reductions in instructional expenditures by school districts. Journal of Education Finance, 37(3), 205-233.

Tserng, H., \& Lin, Y. (2004). Developing an activity-based knowledge management system for contractors. Automation in Construction, 13(6), 781-802.

Tseng, S., \& Fang, Y., (2015). Customer knowledge management performance index: managing and quantifying customer knowledge. Knowledge and Process Management, 22(2), 68-77.

Wang, M. (2011). Measuring intellectual capital and its effect on financial performance: evidence from the capital market in Taiwan. Frontiers of Business Research in China, 5(2), 243-265.

Werner, O., \& Campbell, D. (1970). Translating, working through interpreters, and the problem of decentering. In Naroll, R. and Cohen, R. (Eds.), A handbook of method in cultural anthropology, American Museum of Natural History, New York, NY, 398-420. 


\section{APPENDIX A}

The questionnaire was modified from the questionnaire used by Gold et al., (2001) and Smith (2006).

1. Demographic questions:

Choose your organization's legal status:

\begin{tabular}{lc} 
Partnership & Choose One \\
\hline Limited liability & \\
\hline Sole proprietorship & \\
\hline
\end{tabular}

2. Choose your organization's sector:

Choose One

Private

Public

3. Choose your organization's number of employees in 2015 :

Choose One

$5-49$

$50-99$

$100+$

4. Your organization has training and development plan:

Choose One

\section{Yes}

No 


\section{Item Measures of Technological KM Infrastructure}

My organization uses technology that allows...

3.Neither

agree

1.Strongly nor 5.Strongly

disagree 2.Disagree disagree 4.Agree agree

[TI1]: It to monitor its competition and business partners.

[TI2]: People in multiple locations to learn as a group from a single source or at a single point in time,

[TI3]: People in multiple locations to learn as a group from a multiple source or at multiple points in time.

[T14]: It to map the location (i,e,, an individual, specific system, or database) of specific types of knowledge.

\section{Item Measures of Structural KM Infrastructure}

*Structure is defined as the rules, policies, procedures, processes, hierarchy of reporting relationships, incentive systems, and departments' boundaries that organize tasks within the firm.

My organization('s)...

[S|1]:Structure facilitates the discovery of new knowledge.
[S|2]:Structure facilitates the creation of new knowledge.
[S|3]:Bases our performance on knowledge creation.
[S|4]:Has a standardized reward system for sharing knowledge.
[S|5]:Designs processes to facilitate knowledge exchange across
functional boundaries.
[S|6]:Managers frequently examine knowledge for errors/mistakes.
[S|7]:Structure facilitates the transfer of new knowledge across structural
boundaries.


7. Item Measures of Cultural KM Infrastructure

In my organization ...

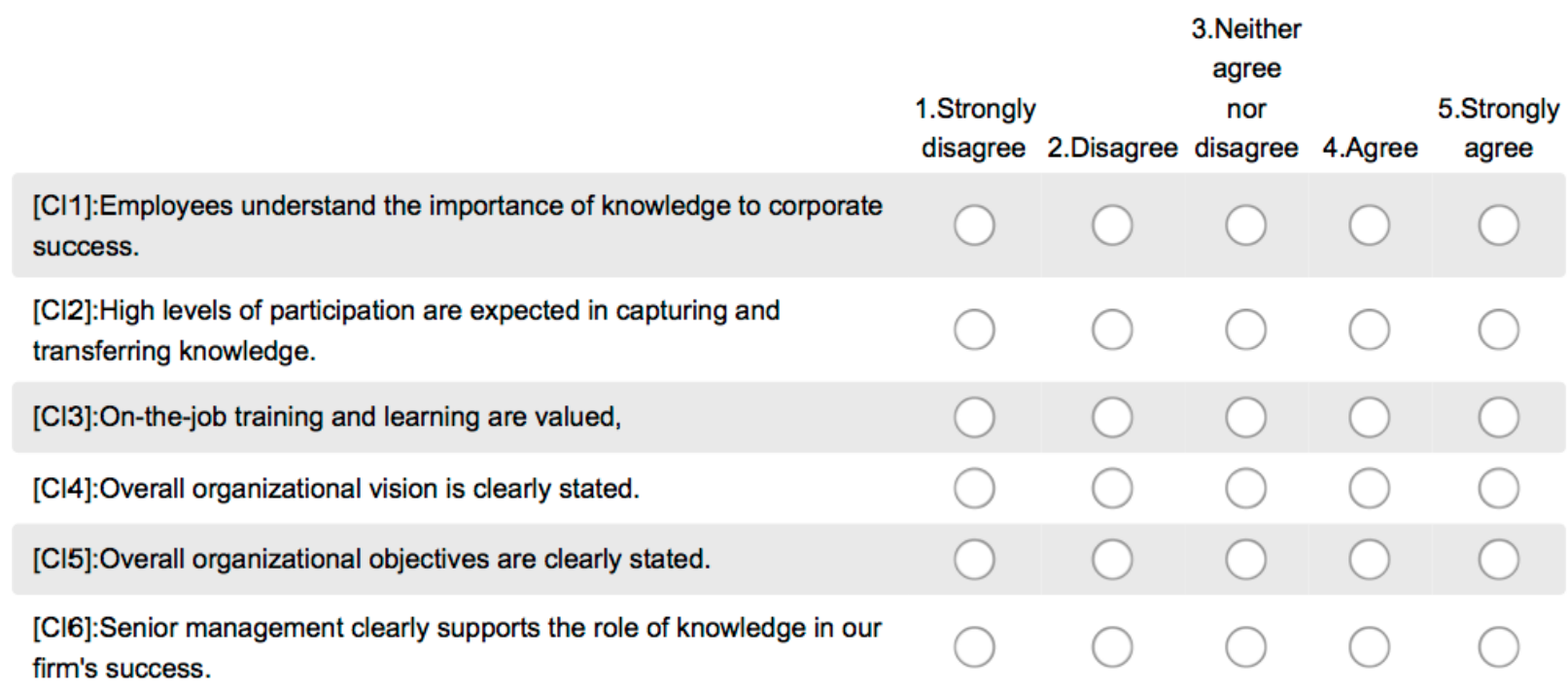

8. Item Measures of KM Acquisition Process

My organization ...

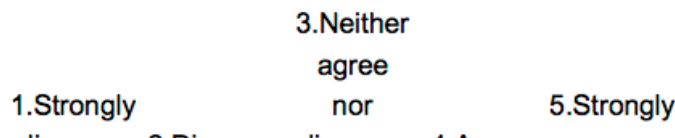

disagree 2.Disagree disagree 4.Agree agree

[AP1]:Has processes for acquiring knowledge about our customers.

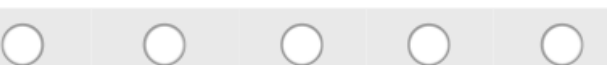

[AP2]:Has processes for generating new knowledge from existing knowledge.

[AP3]:Has processes for acquiring knowledge about our suppliers.

[AP4]:Has processes for distributing knowledge throughout the organization.

[AP5]:Has processes for acquiring knowledge about new products/services within our industry.

[AP6]:Has processes for exchanging knowledge between individuals. 


\section{Item Measures of KM Conversion Process}

My organization ...

[CP1]:Has processes for filtering knowledge.
[CP2]:Has processes for transferring organizational knowledge to
individuals.
[CP3]:Has processes for absorbing knowledge from individuals into the
organization
[CP4]:Has processes for integrating different sources and types of
knowledge.
[CP5]:Has processes for organizing knowledge.
[CP6]:Has processes for replacing outdated knowledge.
disagree 2.Disagree disagree
a.Agree
agree

10. Item Measures of KM Application Process

My organization ... .

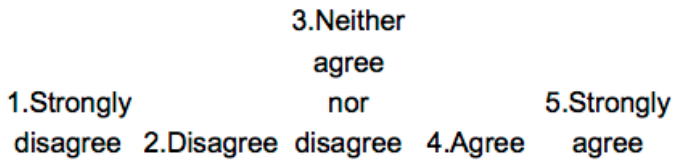

[AP1]:Has processes for using knowledge in development of new products/ services.

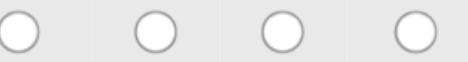

[AP2]:Has processes for using knowledge to solve new problems.

[AP3]:Matches sources of knowledge to problems and challenges.

[AP4]:Uses knowledge to improve efficiency.

[AP5]:Uses knowledge to adjust strategic direction,

[AP6]:Is able to locate and apply knowledge to changing competitive conditions.

[AP7]:Takes advantage of new knowledge, 
11. Item Measures of KM Protection Process

My organization ...

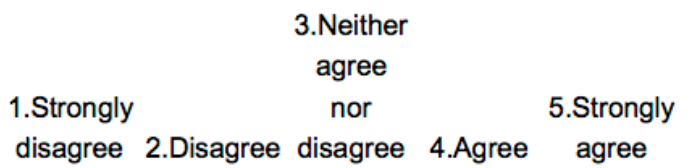

[PP1]:Has processes to protect knowledge from inappropriate use inside
the organization.
[PP2]:Has processes to protect knowledge from inappropriate use
outside the organization,
[PP3]:Has processes to protect knowledge from theft from within the
organization.
[PP4]:Has processes to protect knowledge from theft from outside the
organization.
[PP5]:Has extensive polices and procedures for protecting trade secrets.
[PP6]:Values and protects knowledge embedded in individuals.




\section{Item Measures of Business Performance}

In my organization ...

\begin{tabular}{|c|c|c|c|c|c|}
\hline & \multicolumn{5}{|c|}{$\begin{array}{l}\text { 3.Neither } \\
\text { agree }\end{array}$} \\
\hline & $\begin{array}{l}\text { 1.Strongly } \\
\text { disagree }\end{array}$ & 2.Disagree & $\begin{array}{c}\text { nor } \\
\text { disagree }\end{array}$ & 4.Agree & $\begin{array}{l}\text { 5.Strongly } \\
\text { agree }\end{array}$ \\
\hline \multicolumn{6}{|l|}{$\begin{array}{l}\text { Financial perspective: } \\
\text { [BP1]:Profit growth rate in past year was above industry average in our } \\
\text { company. }\end{array}$} \\
\hline \multicolumn{6}{|l|}{$\begin{array}{l}\text { [BP2]:Return on assets (ROA:how profitable a company is relative to its } \\
\text { total assets) in past year was above industry average in our company. }\end{array}$} \\
\hline \multicolumn{6}{|l|}{$\begin{array}{l}\text { [BP3]:Added value per employee (measure of how well you are 'utilizing' } \\
\text { your employees) in past year was above industry average in our } \\
\text { company. }\end{array}$} \\
\hline \multicolumn{6}{|l|}{$\begin{array}{l}\text { Customer perspective: } \\
{[\mathrm{BP} 4]: \text { We retain existing clients and manage to attract new-ones. }}\end{array}$} \\
\hline \multicolumn{6}{|l|}{$\begin{array}{l}\text { [BP5]:The number of customer complaints within the last period has } \\
\text { decreased strongly. }\end{array}$} \\
\hline \multicolumn{6}{|l|}{$\begin{array}{l}\text { [BP6]:Reputation of our company in eyes of the customers has } \\
\text { improved. }\end{array}$} \\
\hline \multicolumn{6}{|l|}{$\begin{array}{l}\text { Learning and growth perspective: } \\
\text { [BP7]:The net fluctuation of employees (number of staff replaced due to } \\
\text { dissatisfaction with pay, relationships in the workplace and chances for } \\
\text { career advances etc - internal reasons) is very low within our company. }\end{array}$} \\
\hline \multicolumn{6}{|l|}{ [BP8]:Productivity of employees is much higher than industry average. } \\
\hline \multicolumn{6}{|l|}{ [BP9]:Employees feel very committed to the organization. } \\
\hline \multicolumn{6}{|l|}{ [BP10]:Absenteeism is in our company (relative to competition) very low. } \\
\hline \multicolumn{6}{|l|}{$\begin{array}{l}\text { Supplier perspective: } \\
\text { [BP11]:Relationships with key suppliers are excellent. }\end{array}$} \\
\hline \multicolumn{6}{|l|}{$\begin{array}{l}\text { [BP12]:There is a high level of mutual trust among our company and our } \\
\text { suppliers. }\end{array}$} \\
\hline $\begin{array}{l}\text { Internal processes perspective: } \\
\text { [BP13]:We execute business processes far faster than our competitors. }\end{array}$ & & & & & \\
\hline
\end{tabular}




\section{APPENDIX B}

The questionnaire was modified from the questionnaire used by Gold et al., (2001) and Smith (2006).

Item measures of Technological KM Infrastructure

\begin{tabular}{|c|c|c|c|c|c|c|}
\hline \multirow{2}{*}{ Survey Questions } & \multirow{2}{*}{$\begin{array}{c}\mathbf{N} \\
\text { Statistic }\end{array}$} & \multirow{2}{*}{$\begin{array}{c}\text { Minimum } \\
\text { Statistic }\end{array}$} & \multirow{2}{*}{$\begin{array}{c}\text { Maximum } \\
\text { Statistic }\end{array}$} & \multicolumn{2}{|c|}{ Mean } & \multirow{2}{*}{$\begin{array}{c}\text { Std. Deviation } \\
\text { Statistic }\end{array}$} \\
\hline & & & & Statistic & Std. Error & \\
\hline $\begin{array}{l}\text { My organization uses technology } \\
\text { that allows... } \\
\text { TI1 It to monitor its competition } \\
\text { and business partners. }\end{array}$ & 75 & 1 & 5 & 3.92 & 0.104 & 0.897 \\
\hline $\begin{array}{l}\text { TI2 People in multiple locations to } \\
\text { learn as a group from a single } \\
\text { source or at a single point in time. }\end{array}$ & 75 & 1 & 5 & 3.56 & 0.109 & 0.948 \\
\hline $\begin{array}{l}\text { TI3 People in multiple locations to } \\
\text { learn as a group from a multiple } \\
\text { source or at multiple points in time. }\end{array}$ & 75 & 2 & 5 & 3.61 & 0.098 & 0.853 \\
\hline $\begin{array}{l}\text { TI4 It to map the location (i.e., an } \\
\text { individual, specific system, or } \\
\text { database) of specific types of } \\
\text { knowledge. }\end{array}$ & 75 & 1 & 5 & 3.51 & 0.105 & 0.906 \\
\hline
\end{tabular}

\begin{tabular}{|c|c|c|c|c|c|c|}
\hline \multicolumn{7}{|c|}{ Item Measures of Technological KM Infrastructure. My organization usues technology that allows... } \\
\hline Answer Option & $\begin{array}{l}\text { 1. Strongly } \\
\text { disagree }\end{array}$ & 2. Disagree & $\begin{array}{l}\text { 3. Neither agree } \\
\text { nor disagree }\end{array}$ & 4. Agree & $\begin{array}{l}\text { 5. Strongly } \\
\text { agree }\end{array}$ & $\begin{array}{c}\text { Response } \\
\text { Count }\end{array}$ \\
\hline $\begin{array}{l}\text { [IT1]: It to monitor its competition } \\
\text { and business partners }\end{array}$ & 1 & 5 & 12 & 39 & 19 & 75 \\
\hline $\begin{array}{l}\text { [TI2]: People in multiple locations } \\
\text { to learn as a group from a single } \\
\text { source or at a single point in time }\end{array}$ & 1 & 9 & 24 & 29 & 12 & 75 \\
\hline $\begin{array}{l}\text { [TI3]: People in multiple locations } \\
\text { to learn as a group from a m ultiple } \\
\text { source or at multiple points in time. }\end{array}$ & 0 & 8 & 23 & 34 & 10 & 75 \\
\hline $\begin{array}{l}\text { [TI4]: It to map the location (i.e., } \\
\text { an individual specific system or } \\
\text { database) of specific types of } \\
\text { knowledge }\end{array}$ & 2 & 8 & 22 & 36 & 7 & 75 \\
\hline & 75 \\
\hline \multicolumn{6}{|c|}{$\begin{array}{r}\text { Answered Questions } \\
\text { Skipped Questions }\end{array}$} & 0 \\
\hline
\end{tabular}

Item measures of Structural KM Infrastructure

\begin{tabular}{l|c|c|c|c|c|c}
\hline Survey Questions & N & Minimum & Maximum & \multicolumn{2}{c}{ Mean } & Std. Deviation \\
\hline $\begin{array}{l}\text { My organization's ... } \\
\text { SI1 Structure facilitates the discovery of new } \\
\text { knowledge }\end{array}$ & 75 & 2 & 5 & 3.69 & 0.114 & 0.986 \\
\hline $\begin{array}{l}\text { SI2 Structure facilitates the creation of new } \\
\text { knowledge }\end{array}$ & 75 & 2 & 5 & 3.67 & 0.114 & 0.991 \\
\hline $\begin{array}{l}\text { SI3 Bases our performance on knowledge } \\
\text { creation }\end{array}$ & 75 & 1 & 5 & 3.24 & 0.112 & 0.970 \\
\hline $\begin{array}{l}\text { SI4 Has a standardized reward system for } \\
\text { sharing knowledge }\end{array}$ & 75 & 1 & 5 & 2.93 & 0.132 & 1.143 \\
\hline $\begin{array}{l}\text { SI5 Designs processes to facilitate knowledge } \\
\text { exchange across functional boundaries }\end{array}$ & 75 & 1 & 5 & 3.37 & 0.115 & 0.997 \\
\hline $\begin{array}{l}\text { SI6 Managers frequently examine knowledge } \\
\text { for errors/mistakes }\end{array}$ & 75 & 1 & 5 & 3.35 & 0.118 & 1.020 \\
\hline $\begin{array}{l}\text { SI7 Structure facilitates the transfer of new } \\
\text { knowledge across structural boundaries }\end{array}$ & 75 & 1 & 5 & 3.39 & 0.121 & 1.051 \\
\hline
\end{tabular}


Item measures of Cultural KM Infrastructure

\begin{tabular}{|c|c|c|c|c|c|c|}
\hline \multirow{2}{*}{ Survey Questions } & \multirow{2}{*}{$\begin{array}{c}\mathbf{N} \\
\text { Statistic }\end{array}$} & \multirow{2}{*}{$\begin{array}{l}\text { Minimum } \\
\text { Statistic }\end{array}$} & \multirow{2}{*}{$\begin{array}{l}\text { Maximum } \\
\text { Statistic }\end{array}$} & \multicolumn{2}{|c|}{ Mean } & \multirow{2}{*}{$\begin{array}{c}\text { Std. Deviation } \\
\text { Statistic }\end{array}$} \\
\hline & & & & Statistic & Std. Error & \\
\hline $\begin{array}{l}\text { In my organization ... } \\
\text { CI1 Employees understand the } \\
\text { importance of knowledge to corporate } \\
\text { success }\end{array}$ & 75 & 1 & (1) & 3.65 & 0.111 & 0.966 \\
\hline $\begin{array}{l}\text { CI2 High levels of participation are } \\
\text { expected in capturing and transferring } \\
\text { knowledge }\end{array}$ & 73 & 1 & 5 & 3.53 & 0.123 & 1.055 \\
\hline $\begin{array}{l}\mathrm{CI} 3 \text { On-the-job training and learning } \\
\text { are valued }\end{array}$ & 75 & 1 & 5 & 3.68 & 0.123 & 1.067 \\
\hline $\begin{array}{l}\text { CI4 Overall organizational vision is } \\
\text { clearly stated }\end{array}$ & 75 & 1 & 5 & 3.49 & 0.145 & 1.256 \\
\hline $\begin{array}{l}\text { CI5 Overall organizational objectives } \\
\text { are clearly stated }\end{array}$ & 75 & 1 & 5 & 3.71 & 0.126 & 1.088 \\
\hline $\begin{array}{l}\text { CI6 Senior management clearly } \\
\text { supports the role of knowledge in our } \\
\text { firm's success }\end{array}$ & 75 & 1 & 5 & 3.71 & 0.118 & 1.024 \\
\hline
\end{tabular}

\begin{tabular}{|c|c|c|c|c|c|c|}
\hline \multicolumn{7}{|c|}{ Item Measures of Cultural KM Infrastructure. In my organization... } \\
\hline Answer Option & $\begin{array}{l}\text { 1. Strongly } \\
\text { disagree }\end{array}$ & 2. Disagree & $\begin{array}{l}\text { 3. Neither agree } \\
\text { nor disagree }\end{array}$ & 4. Agree & $\begin{array}{l}\text { 5. Strongly } \\
\text { agree }\end{array}$ & $\begin{array}{l}\text { Response } \\
\text { Count }\end{array}$ \\
\hline $\begin{array}{l}\text { [CI1]: Employees understand the } \\
\text { importance of knowledge to } \\
\text { coporate success }\end{array}$ & (n) & 6 & 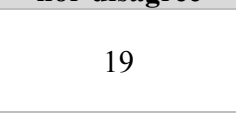 & 36 & 12 & 75 \\
\hline $\begin{array}{l}\text { [CI2]: High levels of participation } \\
\text { are expected in capturing and } \\
\text { transferring knowledge }\end{array}$ & 4 & 8 & 17 & 33 & 11 & 75 \\
\hline $\begin{array}{l}\text { [CI3]: On-the-job training and } \\
\text { learning are valued. }\end{array}$ & 3 & 8 & 16 & 31 & 17 & 75 \\
\hline $\begin{array}{l}\text { [CI4]: Ovrall organizational vision } \\
\text { is clearly stated. }\end{array}$ & 6 & 12 & 15 & 23 & 19 & 75 \\
\hline $\begin{array}{l}\text { [CI5]: Overall organizational } \\
\text { objectives are clearly stated. }\end{array}$ & & & & & & \\
\hline $\begin{array}{l}\text { [CI6]: Senior management clearly } \\
\text { supporst the role of knowledge in } \\
\text { our firms success. }\end{array}$ & & & & & & \\
\hline \multicolumn{6}{|c|}{ Answered Questions } & 75 \\
\hline \multicolumn{6}{|c|}{ Skipped Questions } & 0 \\
\hline KIC Score & 75 & 32 & 83 & 59.92 & 1.324 & 11.470 \\
\hline Valid N (listwise) & 73 & & & & & \\
\hline
\end{tabular}




\begin{tabular}{|c|c|c|c|c|c|c|}
\hline & \multicolumn{5}{|c|}{ Item measures of $\mathrm{KM}$ acquisition process } & \multirow{3}{*}{$\begin{array}{c}\text { Std. Deviation } \\
\text { Statistic }\end{array}$} \\
\hline & \multirow{2}{*}{$\begin{array}{c}\mathbf{N} \\
\text { Statistic }\end{array}$} & \multirow{2}{*}{$\begin{array}{c}\text { Minimum } \\
\text { Statistic }\end{array}$} & \multirow{2}{*}{$\begin{array}{l}\text { Maximum } \\
\text { Statistic }\end{array}$} & \multicolumn{2}{|c|}{ Mean } & \\
\hline & & & & Statistic & Std. Error & \\
\hline $\begin{array}{l}\text { My organization ... } \\
\text { AP1 Has processes for acquiring } \\
\text { knowledge about our consumers }\end{array}$ & 75 & 1 & 5 & 3.55 & 0.101 & 0.874 \\
\hline $\begin{array}{l}\text { AP2 Has processes for } \\
\text { generating new knowledge from } \\
\text { existing knowledge }\end{array}$ & 75 & 2 & 5 & 3.40 & 0.100 & 0.870 \\
\hline $\begin{array}{l}\text { AP3 Has processes for acquiring } \\
\text { knowledge about our suppliers }\end{array}$ & 75 & 1 & 5 & 3.61 & 0.109 & 0.943 \\
\hline $\begin{array}{l}\text { AP4 Has processes for } \\
\text { distributing knowledge } \\
\text { throughout the organization }\end{array}$ & 75 & 1 & 5 & 3.33 & 0.119 & 1.031 \\
\hline $\begin{array}{l}\text { AP5 Has processes for acquiring } \\
\text { knowledge about new } \\
\text { products/services within our } \\
\text { industry. }\end{array}$ & 75 & 1 & 5 & 3.60 & 0.127 & 1.103 \\
\hline $\begin{array}{l}\text { AP6 Has processes for } \\
\text { exchanging knowledge between } \\
\text { individuals }\end{array}$ & 74 & 1 & 5 & 3.43 & 0.126 & 1.086 \\
\hline
\end{tabular}

\begin{tabular}{|c|c|c|c|c|c|c|}
\hline \multicolumn{7}{|c|}{ Item Measures of KM Acquisitions Process. My organization... } \\
\hline Answer Option & $\begin{array}{l}\text { 1. Strongly } \\
\text { disagree }\end{array}$ & 2. Disagree & $\begin{array}{l}\text { 3. Neither agree } \\
\text { nor disagree }\end{array}$ & 4. Agree & $\begin{array}{l}\text { 5. Strongly } \\
\text { agree }\end{array}$ & $\begin{array}{l}\text { Response } \\
\text { Count }\end{array}$ \\
\hline $\begin{array}{l}\text { [AP1]: Has processes for acquiring } \\
\text { knowledge about our customers. }\end{array}$ & 1 & 8 & 23 & 35 & 8 & 75 \\
\hline $\begin{array}{l}\text { [AP2]: Has processes for } \\
\text { generating new knowledge from } \\
\text { existing knowledge. }\end{array}$ & 0 & 14 & 22 & 34 & 5 & 75 \\
\hline $\begin{array}{l}\text { [AP3]: Has processes for acquiring } \\
\text { knowledge about our suppliers. }\end{array}$ & 1 & 9 & 20 & 33 & 12 & 75 \\
\hline $\begin{array}{l}\text { [AP4]: Has processes for } \\
\text { distributing knowledge thoughout } \\
\text { the organization. }\end{array}$ & 1 & 19 & 18 & 28 & 9 & 75 \\
\hline $\begin{array}{l}\text { [AP5]: Has processes for acquiring } \\
\text { knowledge about new } \\
\text { products/services within our } \\
\text { industry. }\end{array}$ & 3 & 11 & 15 & 30 & 16 & 75 \\
\hline $\begin{array}{l}\text { [AP6]: Has processes from } \\
\text { exchanging knowledge between } \\
\text { individuals. }\end{array}$ & 5 & 10 & 16 & 34 & 9 & 74 \\
\hline \multicolumn{6}{|c|}{ Answered Questions } & 75 \\
\hline \multicolumn{6}{|c|}{ Skipped Questions } & 0 \\
\hline
\end{tabular}




\begin{tabular}{|c|c|c|c|c|c|c|}
\hline \multicolumn{7}{|c|}{ Item measures of KM Conversion process } \\
\hline & \multirow{2}{*}{$\begin{array}{c}\mathbf{N} \\
\text { Statistic }\end{array}$} & \multirow{2}{*}{$\begin{array}{c}\text { Minimum } \\
\text { Statistic }\end{array}$} & \multirow{2}{*}{$\begin{array}{c}\text { Maximum } \\
\text { Statistic }\end{array}$} & \multicolumn{2}{|c|}{ Mean } & \multirow{2}{*}{$\begin{array}{c}\text { Std. Deviation } \\
\text { Statistic }\end{array}$} \\
\hline & & & & Statistic & Std. Error & \\
\hline $\begin{array}{l}\text { My organization ... } \\
\text { CP1 Has processes for } \\
\text { filtering knowledge }\end{array}$ & 75 & 1 & 5 & 3.07 & 0.110 & 0.949 \\
\hline $\begin{array}{l}\mathrm{CP} 2 \text { Has processes for } \\
\text { transferring organizational } \\
\text { knowledge to individuals }\end{array}$ & 75 & 1 & 5 & 3.35 & 0.107 & 0.923 \\
\hline $\begin{array}{l}\text { CP3 Has processes for } \\
\text { absorbing knowledge from } \\
\text { individuals into the } \\
\text { organization }\end{array}$ & 75 & 1 & 5 & 3.36 & 0.112 & 0.968 \\
\hline $\begin{array}{l}\text { CP4 Has processes for } \\
\text { integrating different sources } \\
\text { and types of knowledge }\end{array}$ & 75 & 1 & 5 & 3.32 & 0.116 & 1.002 \\
\hline $\begin{array}{l}\text { CP5 Has processes for } \\
\text { organizing knowledge }\end{array}$ & 75 & 1 & 5 & 3.36 & 0.124 & 1.074 \\
\hline $\begin{array}{l}\text { CP6 Has processes for } \\
\text { replacing outdated knowledge }\end{array}$ & 75 & 1 & 5 & 3.28 & 0.112 & 0.966 \\
\hline
\end{tabular}

\begin{tabular}{|c|c|c|c|c|c|c|}
\hline \multicolumn{7}{|c|}{ Item Measures of KM Coversion Process. My organization... } \\
\hline Answer Option & $\begin{array}{l}\text { 1. Strongly } \\
\text { disagree }\end{array}$ & 2. Disagree & $\begin{array}{l}\text { 3. Neither agree } \\
\text { nor disagree }\end{array}$ & 4. Agree & $\begin{array}{l}\text { 5. Strongly } \\
\text { agree }\end{array}$ & $\begin{array}{l}\text { Response } \\
\text { Count }\end{array}$ \\
\hline $\begin{array}{l}\text { [CP1]: Has processes for filtering } \\
\text { knowledge. }\end{array}$ & 2 & 22 & 23 & 25 & 3 & 75 \\
\hline $\begin{array}{l}\text { [CP2]: Has processes for } \\
\text { transferring organizational } \\
\text { knowledge to individuals. }\end{array}$ & 1 & 15 & 21 & 33 & 5 & 75 \\
\hline $\begin{array}{l}\text { [CP3]: Has processes for absorbing } \\
\text { knowledge from individuals into the } \\
\text { organization. }\end{array}$ & 2 & 14 & 20 & 33 & 6 & 75 \\
\hline $\begin{array}{l}\text { [CP4]: Has processes for } \\
\text { integrating differenct sources and } \\
\text { types of knowledge. }\end{array}$ & 1 & 18 & 20 & 28 & 8 & 75 \\
\hline $\begin{array}{l}\text { [CP5]: Has process for organizing } \\
\text { knowledge. }\end{array}$ & 3 & 16 & 16 & 31 & 9 & 75 \\
\hline $\begin{array}{l}\text { [CP6]: Has processes for replacing } \\
\text { outdated knowledge }\end{array}$ & 2 & 15 & 24 & 28 & 6 & 75 \\
\hline \multicolumn{6}{|c|}{ Answered Questions } & 75 \\
\hline \multicolumn{6}{|c|}{ Skipped Questions } & 0 \\
\hline
\end{tabular}


Item measures of KM Application Process

\begin{tabular}{|c|c|c|c|c|c|c|}
\hline & \multirow{2}{*}{$\begin{array}{c}\mathbf{N} \\
\text { Statistic }\end{array}$} & \multirow{2}{*}{$\begin{array}{c}\text { Minimum } \\
\text { Statistic }\end{array}$} & \multirow{2}{*}{$\begin{array}{l}\text { Maximum } \\
\text { Statistic }\end{array}$} & \multicolumn{2}{|c|}{ Mean } & \multirow{2}{*}{$\begin{array}{c}\text { Std. Deviation } \\
\text { Statistic }\end{array}$} \\
\hline & & & & Statistic & Std. Error & \\
\hline $\begin{array}{l}\text { My organization ... } \\
\text { APP1 Has processes for using } \\
\text { knowledge in development of } \\
\text { new products/ services }\end{array}$ & 75 & 1 & 5 & 3.52 & 0.116 & 1.005 \\
\hline $\begin{array}{l}\text { APP2 Has processes for using } \\
\text { knowledge to solve new } \\
\text { problems }\end{array}$ & 75 & 1 & 5 & 3.77 & 0.110 & 0.953 \\
\hline $\begin{array}{l}\text { APP3 Matches sources of } \\
\text { knowledge to problems and } \\
\text { challenges }\end{array}$ & 75 & 1 & 5 & 3.48 & 0.121 & 1.044 \\
\hline $\begin{array}{l}\text { APP4 Uses knowledge to } \\
\text { improve efficiency }\end{array}$ & 75 & 1 & 5 & 3.67 & 0.121 & 1.044 \\
\hline $\begin{array}{l}\text { APP5 Uses knowledge to adjust } \\
\text { strategic direction }\end{array}$ & 75 & 1 & 5 & 3.64 & 0.110 & 0.954 \\
\hline $\begin{array}{l}\text { APP6 Is able to locate and apply } \\
\text { knowledge to changing } \\
\text { competitive conditions }\end{array}$ & 75 & 1 & 5 & 3.52 & 0.113 & 0.978 \\
\hline $\begin{array}{l}\text { APP7 Takes advantage of new } \\
\text { knowledge }\end{array}$ & 75 & 1 & 5 & 3.67 & 0.111 & 0.963 \\
\hline
\end{tabular}

\begin{tabular}{|c|c|c|c|c|c|c|}
\hline \multicolumn{7}{|c|}{ Item Measures of KM Application Process. My organization... } \\
\hline Answer Option & $\begin{array}{l}\text { 1. Strongly } \\
\text { disagree }\end{array}$ & 2. Disagree & $\begin{array}{l}\text { 3. Neither agree } \\
\text { nor disagree }\end{array}$ & 4. Agree & $\begin{array}{l}\text { 5. Strongly } \\
\text { agree }\end{array}$ & $\begin{array}{l}\text { Response } \\
\text { Count }\end{array}$ \\
\hline $\begin{array}{l}\text { [AP1]: Has processes for using } \\
\text { knowledge in development of new } \\
\text { products / services. }\end{array}$ & 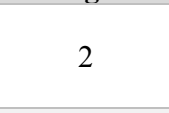 & 12 & 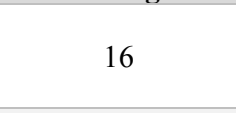 & 32 & 10 & 75 \\
\hline $\begin{array}{l}\text { [AP2]: Has processes for using } \\
\text { knowledge to solve new problems. }\end{array}$ & 1 & 8 & 14 & 36 & 16 & 75 \\
\hline $\begin{array}{l}\text { [AP3:] Matches sources of } \\
\text { knowledge to problems and } \\
\text { challenges. }\end{array}$ & 3 & 11 & 19 & 31 & 11 & 75 \\
\hline $\begin{array}{l}\text { [AP4:]: Uses knowledge to } \\
\text { improve efficiency. }\end{array}$ & 3 & 8 & 15 & 34 & 15 & 75 \\
\hline $\begin{array}{l}\text { [AP5]: Uses knowledge to adjust } \\
\text { strategic direction. }\end{array}$ & 2 & 6 & 22 & 32 & 13 & 75 \\
\hline $\begin{array}{l}\text { [AP6]: Is able to locate and apply } \\
\text { knowledge to changing competitive } \\
\text { conditions. }\end{array}$ & 2 & 10 & 20 & 33 & 10 & 75 \\
\hline $\begin{array}{l}\text { [AP7]: Takes advantage of new } \\
\text { knowledge. }\end{array}$ & 2 & 9 & 12 & 41 & 11 & 75 \\
\hline \multicolumn{6}{|c|}{ Answered Questions } & 75 \\
\hline \multicolumn{6}{|c|}{ Skipped Questions } & 0 \\
\hline
\end{tabular}


Item measures of KM Protection Process

\begin{tabular}{|c|c|c|c|c|c|c|}
\hline & \multirow{2}{*}{$\begin{array}{c}\text { N } \\
\text { Statistic }\end{array}$} & \multirow{2}{*}{$\begin{array}{c}\text { Minimum } \\
\text { Statistic }\end{array}$} & \multirow{2}{*}{$\begin{array}{l}\text { Maximum } \\
\text { Statistic }\end{array}$} & \multicolumn{2}{|c|}{ Mean } & \multirow{2}{*}{$\begin{array}{c}\text { Std. Deviation } \\
\text { Statistic }\end{array}$} \\
\hline & & & & Statistic & Std. Error & \\
\hline $\begin{array}{l}\text { My organization ... } \\
\text { PP1 Has processes to protect } \\
\text { knowledge from inappropriate use } \\
\text { inside the organization }\end{array}$ & 75 & 1 & 5 & 3.59 & 0.114 & 0.988 \\
\hline $\begin{array}{l}\text { PP2 Has processes to protect } \\
\text { knowledge from inappropriate use } \\
\text { outside the organization }\end{array}$ & 75 & 1 & 5 & 3.67 & 0.122 & 1.057 \\
\hline $\begin{array}{l}\text { PP3 Has processes to protect } \\
\text { knowledge from theft from within } \\
\text { the organization }\end{array}$ & 74 & 1 & 5 & 3.38 & 0.129 & 1.107 \\
\hline $\begin{array}{l}\text { PP4 Has processes to protect } \\
\text { knowledge from theft from outside } \\
\text { the organization }\end{array}$ & 75 & 1 & 5 & 3.61 & 0.118 & 1.025 \\
\hline $\begin{array}{l}\text { PP5 Has extensive policies and } \\
\text { procedures for protecting trade } \\
\text { secrets }\end{array}$ & 75 & 1 & 5 & 3.51 & 0.136 & 1.178 \\
\hline $\begin{array}{l}\text { PP6 Values and protects } \\
\text { knowledge embedded in } \\
\text { individuals }\end{array}$ & 75 & 1 & 5 & 3.43 & 0.122 & 1.055 \\
\hline $\begin{array}{l}\text { PP7 Clearly communicates the } \\
\text { importance of protecting } \\
\text { knowledge }\end{array}$ & 75 & 1 & 5 & 3.43 & 0.129 & 1.117 \\
\hline
\end{tabular}

\begin{tabular}{|c|c|c|c|c|c|c|}
\hline \multicolumn{7}{|c|}{ Item Measures of KM Protection Process. My organization... } \\
\hline Answer Option & $\begin{array}{l}\text { 1. Strongly } \\
\text { disagree }\end{array}$ & 2. Disagree & $\begin{array}{l}\text { 3. Neither agree } \\
\text { nor disagree }\end{array}$ & 4. Agree & $\begin{array}{l}\text { 5. Strongly } \\
\text { agree }\end{array}$ & $\begin{array}{c}\text { Response } \\
\text { Count }\end{array}$ \\
\hline $\begin{array}{l}\text { [PP1]: Has processes to protect } \\
\text { knowledge from inappropriate use } \\
\text { inside the organization }\end{array}$ & ond of & 12 & 16 & 34 & 12 & 75 \\
\hline $\begin{array}{l}\text { [PP2]: Has processes to protect } \\
\text { knowledge from inappropriate use } \\
\text { outside the organization. }\end{array}$ & 3 & 8 & 16 & 32 & 16 & 75 \\
\hline $\begin{array}{l}\text { [PP3]: Has processes to protect } \\
\text { knowledge from theft from within } \\
\text { the organization. }\end{array}$ & 3 & 15 & 19 & 25 & 12 & 74 \\
\hline $\begin{array}{l}\text { [PP4]: Has processes to protect } \\
\text { knowledge from theft from outside } \\
\text { the organization. }\end{array}$ & 2 & 11 & 14 & 35 & 13 & 75 \\
\hline $\begin{array}{l}\text { [PP5]: Has extensive policies and } \\
\text { procedure for protecting trade } \\
\text { secrets. }\end{array}$ & 3 & 13 & 22 & 17 & 20 & 75 \\
\hline $\begin{array}{l}\text { [PP6]: Values and protectes } \\
\text { knowledge from embedded in } \\
\text { individulas. }\end{array}$ & 2 & 15 & 18 & 29 & 11 & 75 \\
\hline $\begin{array}{l}\text { [PP7]: Clearly communicates the } \\
\text { importance of protecting } \\
\text { knowledge. }\end{array}$ & 3 & 13 & 23 & 21 & 15 & 75 \\
\hline \multicolumn{6}{|c|}{ Answered Questions } & 75 \\
\hline \multicolumn{6}{|c|}{ Skipped Questions } & 0 \\
\hline
\end{tabular}

\begin{tabular}{l|l|l|l|l|l|l}
\hline KPC Score & 75 & 41 & 130 & 90.44 & 2.097 & 18.165 \\
\hline Valid N (listwise) & 74 & & & & & \\
\hline
\end{tabular}


Item measures of Business Performance

\begin{tabular}{|c|c|c|c|c|c|c|}
\hline & \multirow{2}{*}{$\begin{array}{c}\mathbf{N} \\
\text { Statistic }\end{array}$} & \multirow{2}{*}{$\begin{array}{l}\text { Minimum } \\
\text { Statistic }\end{array}$} & \multirow{2}{*}{$\begin{array}{l}\text { Maximum } \\
\text { Statistic }\end{array}$} & \multicolumn{2}{|c|}{ Mean } & \multirow{2}{*}{$\begin{array}{l}\text { Std. Deviation } \\
\text { Statistic }\end{array}$} \\
\hline & & & & Statistic & Std. Error & \\
\hline $\begin{array}{l}\text { In my organization. . } \\
\text { Financial perspective: } \\
\text { BP1 Profit growth rate in past year } \\
\text { was above industry average in our } \\
\text { company }\end{array}$ & 75 & 1 & 5 & 3.37 & 0.117 & 1.010 \\
\hline $\begin{array}{l}\text { BP2 Return on assets in past year } \\
\text { was above industry average in our } \\
\text { company }\end{array}$ & 75 & 1 & 5 & 3.41 & 0.114 & 0.988 \\
\hline $\begin{array}{l}\text { BP3 Added value per employee in } \\
\text { past year was above industry } \\
\text { average in our company. }\end{array}$ & 75 & 1 & 5 & 3.21 & 0.123 & 1.069 \\
\hline $\begin{array}{l}\text { Consumer perspective: } \\
\text { BP4 We retain existing clients and } \\
\text { manage to attract new-ones }\end{array}$ & 75 & 2 & 5 & 4.17 & 0.097 & 0.844 \\
\hline $\begin{array}{l}\text { BP5 The number of consumer } \\
\text { complaints within the last period } \\
\text { has decreased strongly }\end{array}$ & 75 & 1 & 5 & 3.61 & 0.115 & 0.999 \\
\hline $\begin{array}{l}\text { BP6 Reputation of our company in } \\
\text { eyes of the consumers has } \\
\text { improved }\end{array}$ & 75 & 1 & 5 & 3.84 & 0.106 & 0.916 \\
\hline $\begin{array}{l}\text { Learning and growth perspective: } \\
\text { BP7 The net fluctuation of } \\
\text { employees is very low within our } \\
\text { company. }\end{array}$ & 75 & 1 & 5 & 3.25 & 0.142 & 1.231 \\
\hline $\begin{array}{l}\text { BP8 Productivity of employees is } \\
\text { much higher than industry average }\end{array}$ & 75 & 1 & 5 & 3.07 & 0.119 & 1.031 \\
\hline $\begin{array}{l}\text { BP9 Employees feel very } \\
\text { committed to the organization }\end{array}$ & 74 & 1 & 5 & 3.36 & 0.128 & 1.105 \\
\hline $\begin{array}{l}\text { BP10 Absenteeism is in our } \\
\text { company (relative to competition) } \\
\text { very low }\end{array}$ & 74 & 1 & 5 & 3.45 & 0.116 & 0.995 \\
\hline $\begin{array}{l}\text { Supplier perspective: } \\
\text { BP11 Relationships with key } \\
\text { suppliers are excellent }\end{array}$ & 74 & 1 & 5 & 3.88 & 0.107 & 0.921 \\
\hline $\begin{array}{l}\text { BP12 There is a high level of } \\
\text { mutual trust among our company } \\
\text { and our suppliers }\end{array}$ & 74 & 2 & 5 & 3.95 & 0.092 & 0.792 \\
\hline $\begin{array}{l}\text { Internal processes perspective: } \\
\text { BP13 We execute business } \\
\text { processes far faster than our } \\
\text { competitors }\end{array}$ & 75 & 1 & 5 & 3.40 & 0.119 & 1.027 \\
\hline $\begin{array}{l}\text { BP14 We execute business } \\
\text { processes far cheaper than our } \\
\text { competitors }\end{array}$ & 75 & 1 & 5 & 3.15 & 0.112 & 0.968 \\
\hline OP Score & 75 & 21 & 70 & 48.93 & 1.112 & 9.633 \\
\hline Valid N (listwise) & 72 & & & & & \\
\hline
\end{tabular}




\begin{tabular}{|c|c|c|c|c|c|c|}
\hline \multicolumn{7}{|c|}{ Item Measures of Business Preformance. My organization... } \\
\hline Answer Option & $\begin{array}{l}\text { 1. Strongly } \\
\text { disagree }\end{array}$ & 2. Disagree & $\begin{array}{l}\text { 3. Neither agree } \\
\text { nor disagree }\end{array}$ & 4. Agree & $\begin{array}{l}\text { 5. Strongly } \\
\text { agree }\end{array}$ & $\begin{array}{c}\text { Response } \\
\text { Count }\end{array}$ \\
\hline $\begin{array}{l}\text { Financial prespective [BP1]: Profit } \\
\text { growth rate in past year was above } \\
\text { insutry averave in our company }\end{array}$ & 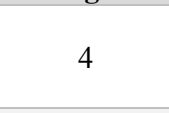 & 11 & 19 & 35 & 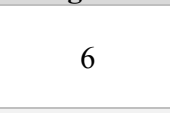 & 75 \\
\hline $\begin{array}{l}\text { [BP2]: Return on assets in the past } \\
\text { year was above industry average in } \\
\text { our company. }\end{array}$ & 2 & 12 & 23 & 29 & 9 & 75 \\
\hline $\begin{array}{l}\text { [BP3]: Added value per employee } \\
\text { in past year was above industry } \\
\text { averabe in our company. }\end{array}$ & 5 & 13 & 26 & 12 & 8 & 75 \\
\hline $\begin{array}{l}\text { Customer prespective: [BP4]: We } \\
\text { retain existing clients and manage } \\
\text { to attract new-ones. }\end{array}$ & 0 & 3 & 12 & 29 & 31 & 75 \\
\hline $\begin{array}{l}\text { [BP5]: The number of customer } \\
\text { complaints within the last period } \\
\text { has decreasted strongly. }\end{array}$ & 3 & 5 & 24 & 29 & 14 & 75 \\
\hline $\begin{array}{l}\text { [BP6]: Reputation of our company } \\
\text { in yeys of the customer has } \\
\text { improved. }\end{array}$ & 1 & 614 & 37 & 17 & & 75 \\
\hline $\begin{array}{l}\text { Learning and growth prespective: } \\
\text { [BP7]: The new fluctuation of } \\
\text { employees is ver low within our } \\
\text { company. }\end{array}$ & 9 & 11 & 18 & 26 & 11 & 75 \\
\hline $\begin{array}{l}\text { [BP8]: Productivity of employees } \\
\text { is much hight than industry } \\
\text { average. }\end{array}$ & 6 & 13 & 32 & 18 & 6 & 75 \\
\hline $\begin{array}{l}\text { [BP9]: Employees feel very } \\
\text { commiteed to the organization }\end{array}$ & 4 & 14 & 17 & 29 & 10 & 74 \\
\hline $\begin{array}{l}\text { [BP10]: Absenteeism is in our } \\
\text { company (relative to competition) } \\
\text { is very low. }\end{array}$ & 3 & 9 & 23 & 30 & 9 & 74 \\
\hline $\begin{array}{l}\text { Supplier prespective: [BP11]: } \\
\text { Relationships with key suppliers } \\
\text { are excellent. }\end{array}$ & 2 & 1 & 21 & 30 & 20 & 74 \\
\hline $\begin{array}{l}\text { [BP12]: There is a high lever of } \\
\text { mutual trust among our company } \\
\text { and our suppliers. }\end{array}$ & 2 & 1 & 21 & 30 & 20 & 74 \\
\hline $\begin{array}{l}\text { Internal processes prespective: } \\
\text { [BP13]: We excute business } \\
\text { processes far faster than our } \\
\text { competitors. }\end{array}$ & 1 & 16 & 21 & 26 & 11 & 75 \\
\hline $\begin{array}{l}\text { [BP14]: We execute business } \\
\text { processes for cheaper than our } \\
\text { competitors. }\end{array}$ & 1 & 20 & 28 & 19 & 7 & 75 \\
\hline \multicolumn{6}{|c|}{ Answered Questions } & 75 \\
\hline \multicolumn{6}{|c|}{ Skipped Questions } & 0 \\
\hline
\end{tabular}


NOTES 